\title{
Karst Geoheritage and Geotourism Potential in the Pek River Lower Basin (Eastern Serbia)
}

\author{
Aleksandar Antić ${ }^{A}$, Nemanja Tomić ${ }^{A^{*}}$, Slobodan Marković ${ }^{A}$ \\ Received: February 06, 2019 | Revised: March 08, 2019 | Accepted: March 09, 2019
}

DOI: $10.5937 / g p 23-20463$

\begin{abstract}
Karst areas, as areas with attractive geological and geomorphological features are an important and integral part of geoheritage. They possess huge tourism potential and can be used for the development of geotourism. The Pek River basin is a highly dominant karst terrain with numerous geological and geomorphological features, especially caves. However, their geotourism potential still remains fully unrevealed. In this paper, we analyzed several geosites that represent significant karst geoheritage formations and as such they can be the backbone of future geotourism development in this area. The aim of this paper is to emphasize the geotourism potential of the Pek River lower basin and to determine the current state and geotourism potential of these geosites by applying the modified geosite assessment model (M-GAM).
\end{abstract}

Keywords: geotourism; M-GAM; karst geoheritage; Eastern Serbia; Pek River

\section{Introduction}

Karst geosites, as areas with attractive karst process features, represent a very important part of geoheritage and possess outstanding qualities and potentials that can be used for the development and improvement of geotourism. These type of terrains fall within the category of special environments and they are a significant component of what is referred to as the 'earth's geodiversity' (Gray, 2004). Their unique features, fossil and archaeological remains make them an interesting tourism resource with a high economic value.

When it comes to karst tourism in Eastern Serbia, the potentials for its development are numerous and of great importance, both for the region and for the local population. Tourism development and an increase in visitor numbers could be the initial trigger for the restoration and improvement of social and business activities in this region. The highly dominant karst terrain in this area has led to the development of numerous surface and underground geomorphologi- cal features. This part of Serbia possesses a large number of caves (over 1000 caves) and other karst geosites on a relatively small territory $\left(12000 \mathrm{~km}^{2}\right)$ making it one of the areas with the highest concentration of karst geosites (especially caves) in Serbia (Tomić, 2011). The Pek River lower basin is an excellent example of this because it has numerous karst geosites that possess significant geotourism values and potentials. All of the geosites analyzed in this paper are located on the territory of Kučevo municipality in the Braničevo district (eastern Serbia). They represent the most significant karst formation sites for geotourism development in this area. For the purposes of this paper, the area of the Pek River lower basin is defined as the area of the territory of Kučevo municipality.

During the past two decades, geotourism has become an increasingly popular form of tourism throughout the world (Ruban, 2015). It primarily depends on geosites (geological heritage) which identifi-

\footnotetext{
A University of Novi Sad, Faculty of Sciences, Department of Geography, Tourism and Hotel Management, Trg Dositeja Obradovića 3, 21000 Novi Sad, Serbia; a.antic994@gmail.com; airtomic@gmail.com; slobodan.markovic@dgt.uns.ac.rs

* Corresponding author: Nemanja Tomić; e-mail: airtomic@gmail.com; +381692355380
} 
cation and subsequent assessment are important steps in the process of geotourism development and protection of geosites (Štrba, 2018). Quantifying and assessing the value of geosites to potential visitors and researchers is widely recognized as a useful tool for the effective development and management and for the protection of geological heritage of a certain area. As response to this, numerous authors have focused their research on geosite assessment and geoheritage evaluation (Brilha, 2016; Fassoulas et al., 2012; Kubalíková \& Kirchner, 2016; Różycka \& Migoń, 2014; Różycka \& Migoń, 2018; Rybár, 2010; Štrba, 2015; Štrba et al., 2015; Tičar et al., 2018; Tomić \& Božić, 2014; Tomić et al., 2018) in order to better assess the current state and geotourism potential of geosites which would further lead to an improvement of geosite management and enable sustainable geotourism development. Based on the internationally accepted concept of geotourism, an importance of geosite identifications and assessments is undisputable, with special emphasis on presentation of geosites to the general public which interest is essential for geotourism progress. The main objectives of geotourism include promotion and protection of geoheritage throughout tourism activities along with educational and interpretive elements in order to in- crease the awareness of the wider public for conservation needs as well as sustainable development of the tourism industry (Suzuki \& Takagi, 2018). These core elements of geotourism have been confirmed multiple times by various authors in the past (Dowling \& Newsome, 2010; Farsani et al., 2014; Hose, 2000; Hose \& Vasiljević, 2012; Pralong, 2006;) and have proven as key concepts of geotourism.

The main goal of this paper is to present the karst geoheritage of the Pek River lower basin as well as to determine and compare the current state and karst tourism potential of geosites located in this area. Our research included nine geosites (Ceremošnja Cave, Ravništarka Cave, Dubočka Cave, Ševička Cave, Zviška Intermittent Spring, Siga Waterfall, Burev Waterfall, Little Spring Waterfall and Šumeća Karst Spring) which were analyzed by using the M-GAM (Modified Geosite Assessment Model) model (Tomić \& Božić, 2014) for geosite assessment. The results of the analysis should provide information about the major fields of improvement and identify which areas require more attention and better management in the future in order for this area to become a well-known karst tourism destination which would attract a larger number of tourists in the future.

\section{Study area}

The Pek River lower basin (Figure 1) is located in eastern Serbia at the southeastern part of the Pannonian basin. The Pek River is the right tributary of the Danube River and its valley stretches in the SE-NW direction. It is composite and slightly tilted in the NW direction towards the Pannonian basin (Vujadinović, 1953). Our explored area includes four speleological objects (Ceremošnja Cave, Ravništarka Cave, Dubočka Cave, Ševička Cave), one intermittent spring (Zviška), three waterfalls (Siga Waterfall, Burev Waterfall, Little Spring Waterfall) and one karst spring (Šumeća Karst Spring). All of these geosites are located in the Pek River lower basin, in the municipality of Kučevo and are connected by the Pek River.

Ceremošnja Cave is located on the Northwestern slopes of Homolje Mountains, at an altitude of $533 \mathrm{~m}$, at the foot of their highest peak, Veliki Štubej (940 m) in the Ceremošnja village. The cave was arranged for tourist visits in 1980 and it has been protected on a national level as a natural monument level since 2007. It is located $15 \mathrm{~km}$ from the town of Kučevo and together with the Ravništarka Cave it is the only one open for visits even though there are 16 other caves in the vicinity. The total length of the explored cave passages so far is $775.5 \mathrm{~m}$, while the length of the tourist trail is $431 \mathrm{~m}$. With its numerous and picturesque cave or- naments (Figure 2 and Figure 3 ) it is considered as one of the most beautiful caves in Serbia (Lazarević, 1988). Its management has been entrusted to the tourist organization of Kučevo.

Ravništarka Cave is located in the immediate vicinity of the Ceremošnja Cave, in the village of Ravnište which belongs to the basin of Kučajna river, the left tributary of the Pek river. The length of its main passageway is $501.5 \mathrm{~m}$, and the total length of all passageways is $589 \mathrm{~m}$. The total surface of the cavity system is $2.908 \mathrm{~m}^{2}$ and the volume is about 20.000 $\mathrm{m}^{3}$. This cave was adapted for tourist visits in 2007 when it was also declared as a natural monument. The total length of the tourist trail is $535 \mathrm{~m}$. Unlike Ceremošnja Cave, which is essentially a set of several large halls, Ravništarka Cave (Figures 4 and 5) has only one hall called "Black Castle". The cave entrance is $12.5 \mathrm{~m}$ wide and is located at an altitude of $406.6 \mathrm{~m}$. On the plateau above the cave there is an info centre with a restaurant and souvenir shop (Lazarević, 1993).

Ševička Cave or "Vrteč" cave is located in the Ševica village, about $5 \mathrm{~km}$ from the local asphalt road. The cave is about $400 \mathrm{~m}$ long and is mainly visited by speleology enthusiasts and adventurers which is also the case with the much more famous Dubočka Cave located nearby (Lazarević, 2001). The first part of the 
LEGEND

Geosites

1.Ceremošnja Cave 2.Ravništarka Cave 3.Ševička Cave 4.Dubočka Cave 5. Zviška Spring 6.Siga Waterfall 7.Malo Vrelo Waterfall 8.Burev Waterfall 9.Šumeća Karst Spring Road Network

- IB National Road

— Other Roads

\#ailway

Pek River

Forests

Contours

Research Area

- Settlements

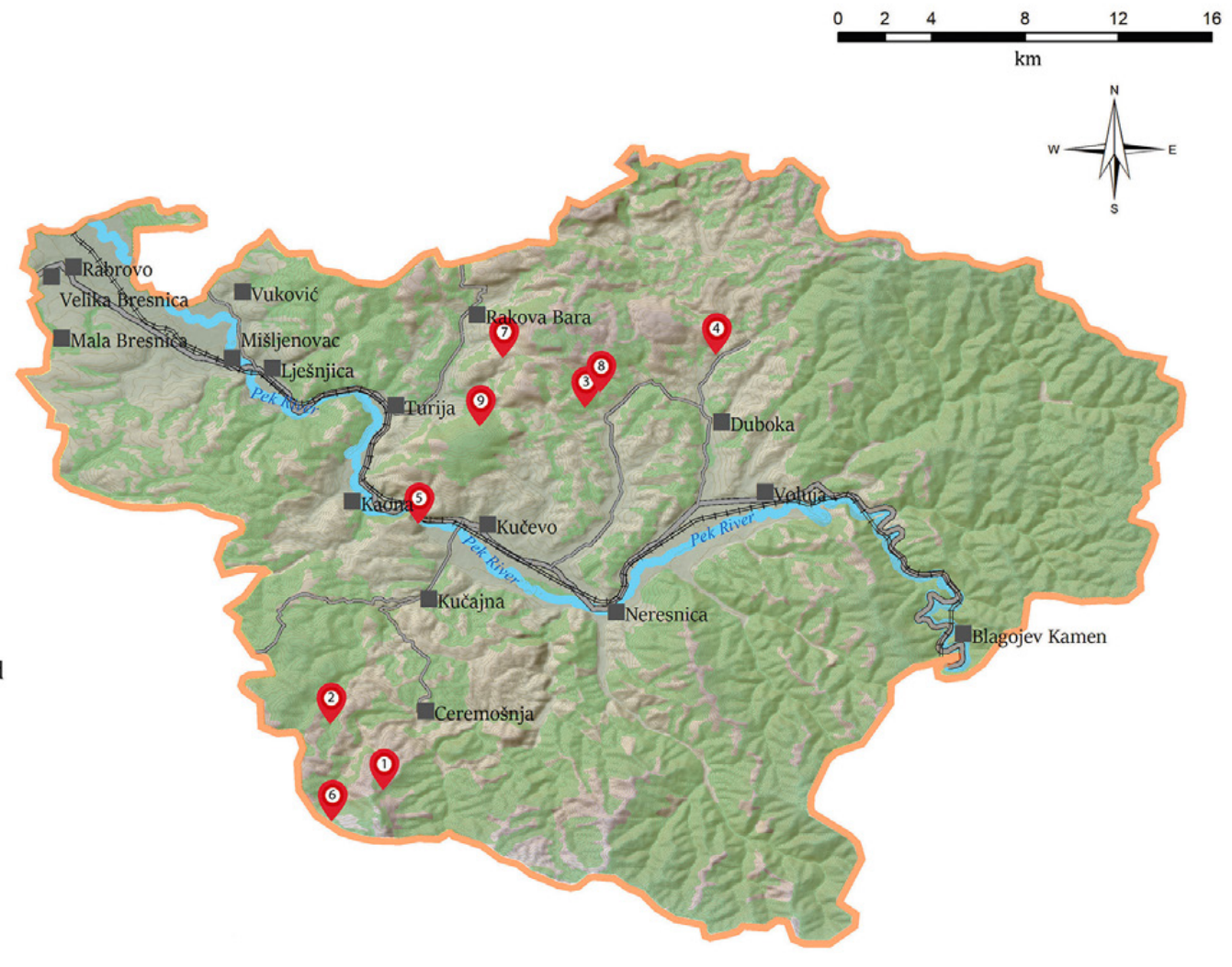

Figure 1. Location of the analyzed geosites in the Pek River lower basin Source: Authors

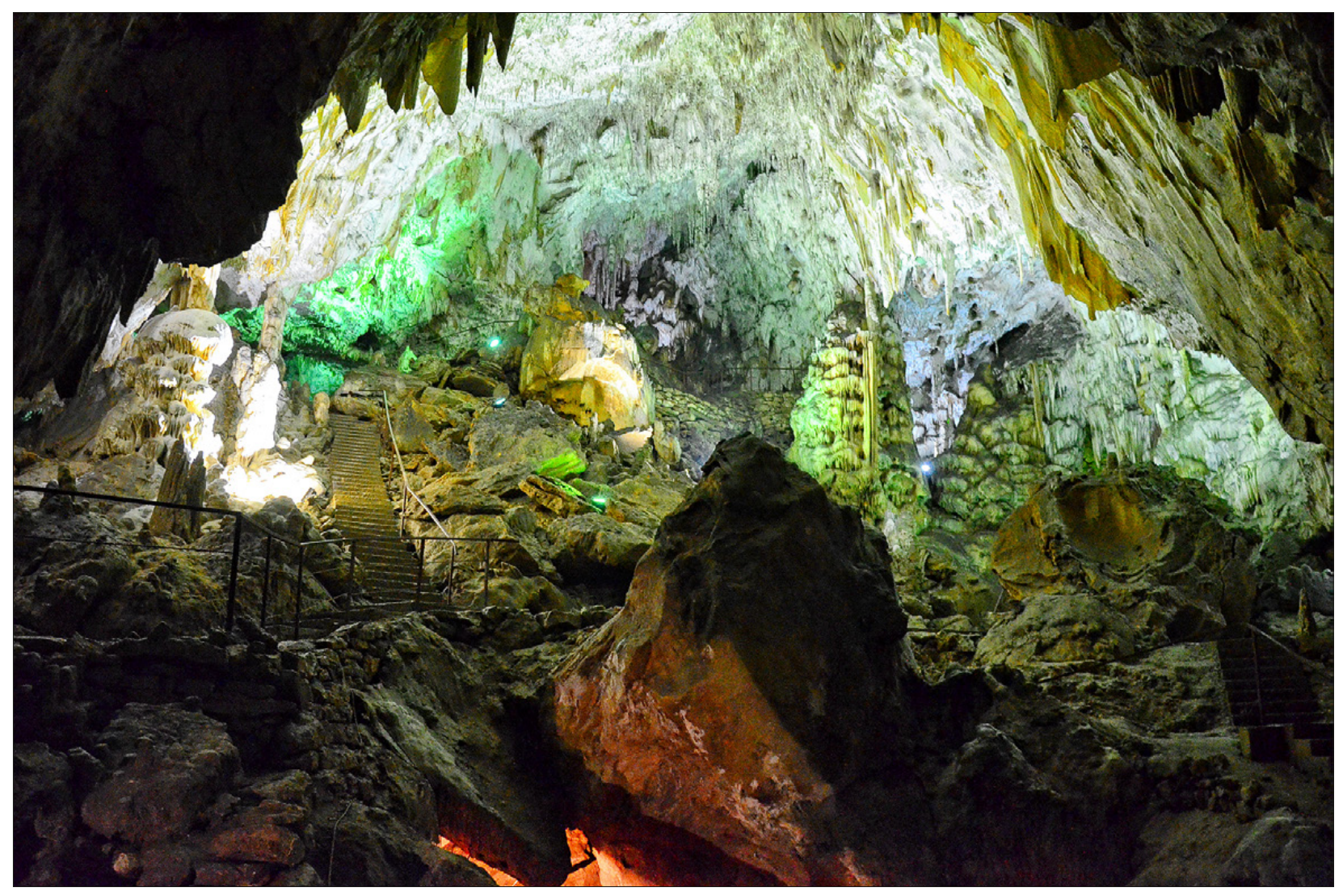

Figure 2. The main hall of Ceremošnja Cave Photo: Nemanja Tomić 


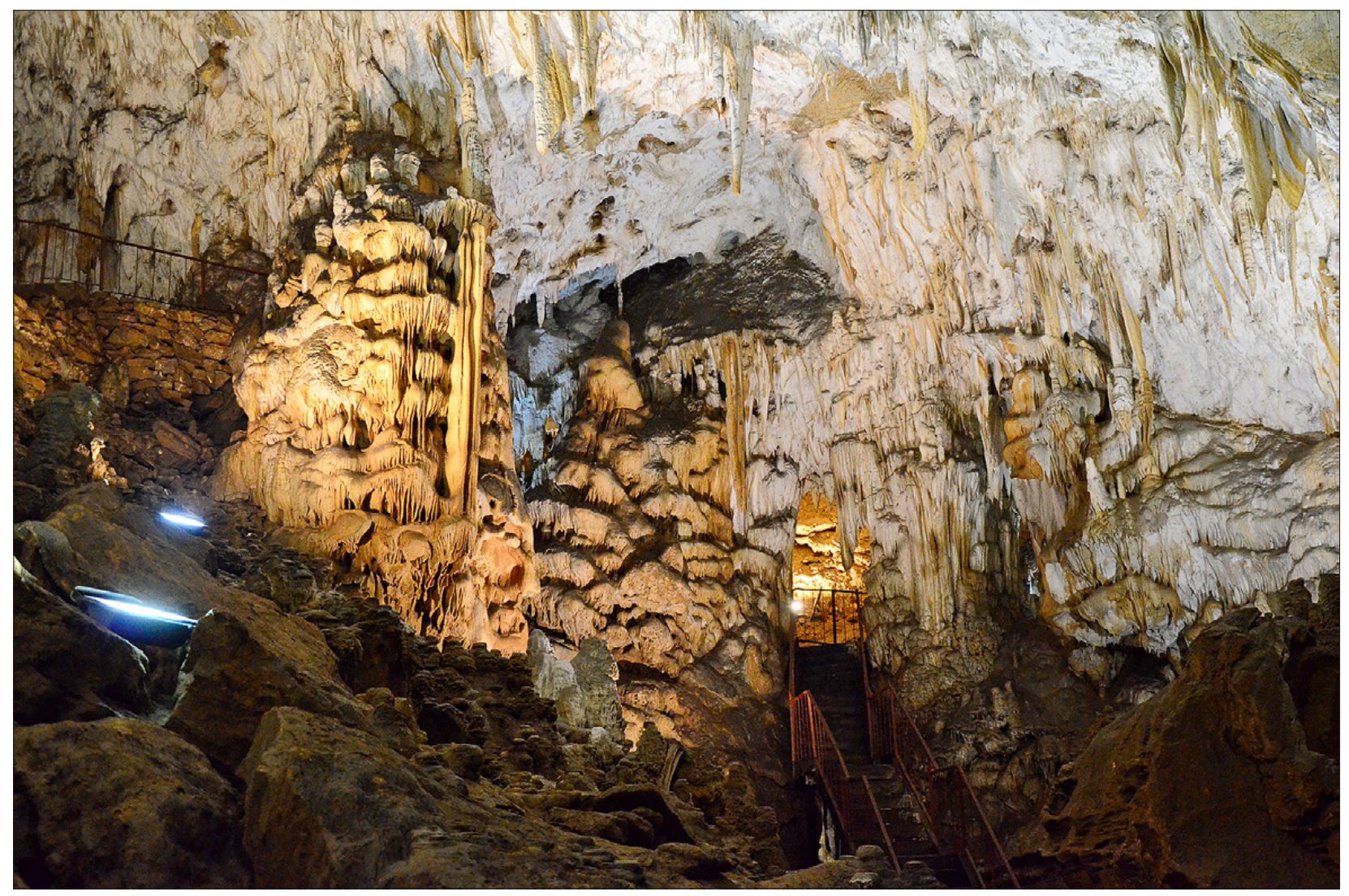

Figure 3. Cave ornaments in Ceremošnja Cave Photo: Nemanja Tomić

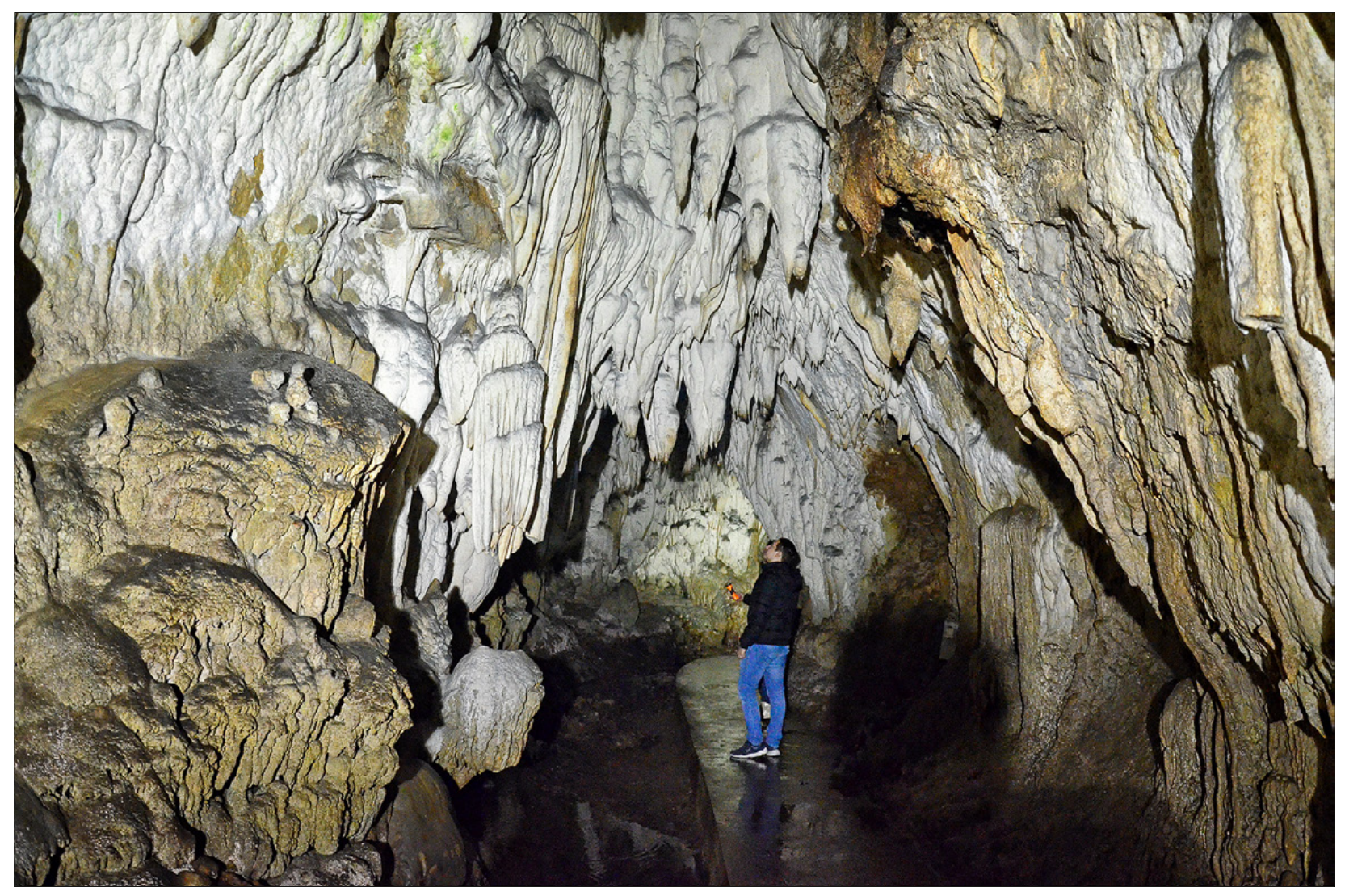

Figure 4. Cave ornaments in Ravništarka Cave Photo: Nemanja Tomić 


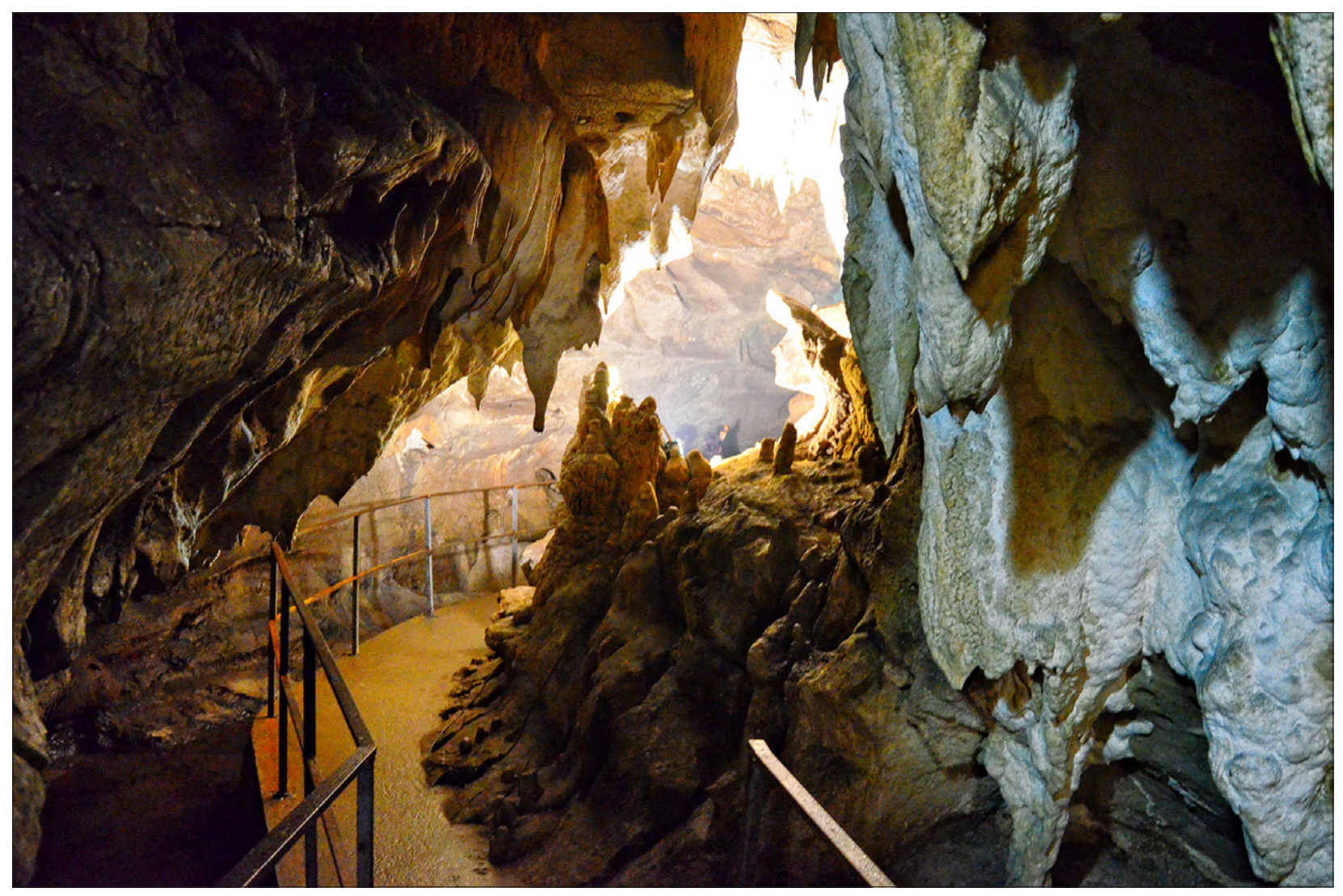

Figure 5. Part of the tourist trail in Ravništarka Cave Photo: Nemanja Tomić

cave is easily accessible to all visitors while the deeper parts of the cave are reserved for trained speleologists.

Dubočka Cave is the largest speleological object in the Pek River basin with good conditions for partial tourist arrangement. This geosite is located $12 \mathrm{~km}$ from Kučevo, near Duboka village, at the foot of a high limestone cliff.

This large cave has a one kilometer long main passageway. The entrance is $16 \mathrm{~m}$ wide and $15 \mathrm{~m}$ high (Lazarević, 2001). The cave system consists of three main parts: Main passageway, Glinoviti and Rusaljkin passageway and a river flows through the cave system.

Zviška Intermittent Spring is located on the right side of the Pek River, at the beginning of Kaona gorge. It is less than 100 meters away from the main road Belgrade-Kučevo giving it the most favorable position of all analyzed geosites. Its main source is located at the foot of a steep limestone slope on the right valley side of the Pek River. It has a funnel shaped opening of 1.15 X $1.0 \mathrm{~m}$ and a depth of $1.10 \mathrm{~m}$ (Lazarević, 1991).

Siga Waterfall is located $4 \mathrm{~km}$ away from the Ceremošnja Cave. It is a $30 \mathrm{~m}$ high cascade waterfall located right below the source of the Siga stream. The waterfall can be reached by car but not by bus, since the road is not asphalted. In the past few years, the wa- terfall has been drying out in early summer (Rajković, 2014). This geosite represents one of the most famous waterfalls in eastern Serbia and certainly the most visited in the Kučevo municipality.

Malo Vrelo (Little Spring Waterfall) is located 16 $\mathrm{km}$ from Kučevo, in the village of Rakova Bara. This waterfall represents a wide area that includes a strong karst spring, which immediately forms a stream with a sloping curve in the length of $150 \mathrm{~m}$, and then crashes down in a vertical cascade waterfall about $15 \mathrm{~m}$ high. The stream also created a short $200 \mathrm{~m}$ gorge along with a few smaller waterfalls ranging from two to eight meters in height. The Little Spring Waterfall can be reached by the regional road Kučevo - Golubac (Krešić, 1988). Its source together with its stream and waterfalls represents a unique geomorphological complex of unusual beauty.

Burev Waterfall is located near the village of Ševica, at a place called Burev, close to Ševica river and Ševička Cave, the right tributary of the river Pek. A stream originates from a strong karst spring and after $50 \mathrm{~m}$ it forms several smaller streams which fall over a $30 \mathrm{~m}$ wide terrace creating a large number of miniature cascade waterfalls (Krešić, 1988). The Burev Waterfall is located $13 \mathrm{~km}$ away from Kučevo and one klometer away from the local asphalt road. 


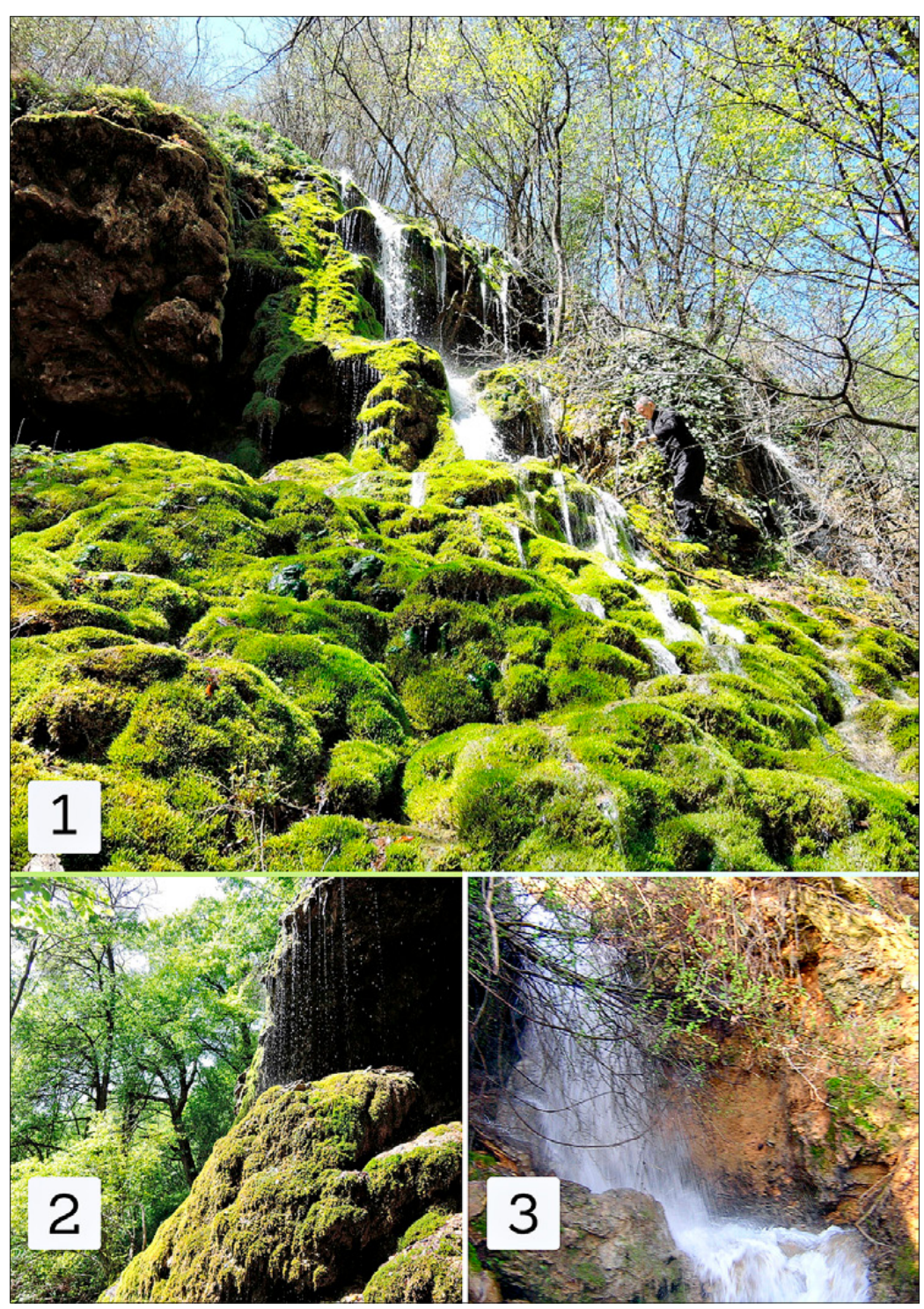

Figure 6. Siga (1), Burev (2) and Malo Vrelo (3) Waterfalls Source: http://www.tokucevo.org/vodopadi-i-vrela/

Šumeća Karst Spring is located in the vicinity of Turija village, $12 \mathrm{~km}$ from the center of Kučevo. This karst spring is the strongest spring in the municipality of Kučevo. From the small cave opening at the foot of the northern slopes of the mountain massif
'Đula', clean water bursts out and immediately forms a strong stream. Several hundred meters downstream from the spring it powers a few rural watermills. During the drought period, spring water discharge is reduced to barely 10 l/s (Krešić, 1988).

\section{Methodology}

The methodology of this study is based upon the 'modified geosite assessment model' (M-GAM), developed by Tomić \& Božić (2014). The M-GAM represents a modification of GAM model created by Vujičić et al. (2011). This method is based on previous geosite assessment methods developed by different authors (Bruschi \& Cendrero, 2005; Coratza \& Giusti, 2005; Erhartič, 2010; Hose, 1997; Pereira et al., 2007; Pralong, 2005; Reynard, 2008; Reynard et al., 2007; Serrano \& González-Trueba, 2005; Tomić, 2011; Zouros, 2007). It combines the opinion of both sides, tourists and experts, in such a way that neither side is favoured in the assessment process. It has been successfully tested and applied numerous times for the assessment of various geosites (Antić \& Tomić, 2017; Boškov et al., 2015; Božić et al., 2014; Božić \& Tomić, 2015; Tičar et al., 2018; Tomić et al., 2015; Tomić et al., 2018; Vukoičić et al., 2018).

The M-GAM model consists of two key indicators: Main Values and Additional Values, which are 
Table 1. The structure of Modified Geosite Assessment Model (M-GAM)

\begin{tabular}{|c|c|c|c|c|c|}
\hline \multicolumn{2}{|c|}{ Indicators/Subindicators } & \multicolumn{4}{|l|}{ Description } \\
\hline \multicolumn{6}{|c|}{ Main values (MV) } \\
\hline \multicolumn{6}{|c|}{ Scientific/Educational value (VSE) } \\
\hline \multicolumn{2}{|c|}{ 1. Rarity } & \multicolumn{4}{|c|}{ Number of closest identical sites } \\
\hline \multicolumn{2}{|c|}{ 2. Representativeness } & \multicolumn{4}{|c|}{ Didactic and exemplary characteristics of the site due to its own quality and general configuration } \\
\hline \multicolumn{2}{|c|}{$\begin{array}{l}\text { 3. Knowledge on geoscientific } \\
\text { issues }\end{array}$} & \multicolumn{4}{|c|}{ Number of written papers in acknowledged journals, thesis, presentations and other publications } \\
\hline \multicolumn{2}{|c|}{ 4. Level of interpretation } & \multicolumn{4}{|c|}{$\begin{array}{l}\text { Level of interpretive possibilities on geological and geomorphologic processes, phenomena and shapes } \\
\text { and level of scientific knowledge }\end{array}$} \\
\hline \multicolumn{6}{|c|}{ Scenic/Aesthetic (VSA) } \\
\hline \multicolumn{2}{|c|}{ 5. Viewpoints } & \multicolumn{4}{|c|}{$\begin{array}{l}\text { Number of viewpoints accessible by a pedestrian pathway. Each must present a particular angle of view } \\
\text { and be situated less than } 1 \mathrm{~km} \text { from the site. }\end{array}$} \\
\hline \multicolumn{2}{|c|}{ 6. Surface } & \multicolumn{4}{|c|}{ Whole surface of the site. Each site is considered in quantitative relation to other sites } \\
\hline \multicolumn{2}{|c|}{$\begin{array}{l}\text { 7. Surrounding landscape and } \\
\text { nature }\end{array}$} & \multicolumn{4}{|c|}{$\begin{array}{l}\text { Panoramic view quality, presence of water and vegetation, absence of human-induced deterioration, } \\
\text { vicinity of urban area, etc. }\end{array}$} \\
\hline \multicolumn{2}{|c|}{$\begin{array}{l}\text { 8. Environmental fitting } \\
\text { of sites }\end{array}$} & \multicolumn{4}{|c|}{ Level of contrast to the nature, contrast of colors, appearance of shapes, etc. } \\
\hline \multicolumn{6}{|c|}{ Protection (VPr) } \\
\hline \multicolumn{2}{|c|}{ 9. Current condition } & \multicolumn{4}{|c|}{ Current state of geosite } \\
\hline \multicolumn{2}{|c|}{ 10. Protection level } & \multicolumn{4}{|c|}{ Protection by local or regional groups, national government, international organizations, etc. } \\
\hline 11. Vu & erability & Vulnerability level & site & & \\
\hline 12. Su & able number of visitors & $\begin{array}{l}\text { Proposed number } \\
\text { current state of ge }\end{array}$ & ors on the site at the san & time, according to surfa & area, vulnerability and \\
\hline Addit & ral values (AV) & & & & \\
\hline Funct & nal values (VFn) & & & & \\
\hline 13. A & ssibility & Possibilities of app & ng to the site & & \\
\hline 14. A & tional natural values & Number of additio & tural values in the radius & $5 \mathrm{~km}$ (geosites also inc & \\
\hline $\begin{array}{l}\text { 15. A } \\
\text { value }\end{array}$ & tional anthropogenic & Number of additio & thropogenic values in the & dius of $5 \mathrm{~km}$ & \\
\hline 16. V & ity of emissive centers & Closeness of emiss & nters & & \\
\hline $\begin{array}{l}\text { 17. Vi } \\
\text { netw }\end{array}$ & ity of important road & Closeness of impor & oad networks in the in ra & us of $20 \mathrm{~km}$ & \\
\hline 18. A & tional functional values & Parking lots, gas st & mechanics, etc. & & \\
\hline Touri & e values (VTr) & & & & \\
\hline 19. $\mathrm{Pr}$ & notion & Level and number & motional resources & & \\
\hline 20. 0 & anized visits & Annual number of & ized visits to the geosite & & \\
\hline 21. V & ity of visitors centers & Closeness of visitor & er to the geosite & & \\
\hline 22. In & pretative panels & Interpretative char & stics of text and graphics & naterial quality, size, fit & to surroundings, etc. \\
\hline 23. $\mathrm{N}$ & ber of visitors & Annual number of & & & \\
\hline 24. Tc & ism infrastructure & $\begin{array}{l}\text { Level of additional } \mathrm{i} \\
\text { etc.) }\end{array}$ & ructure for tourist (pedes & an pathways, resting pla & , garbage cans, toilets \\
\hline 25. Tc & guide service & If exists, expertise & knowledge of foreign lan & age(s), interpretative sk & etc. \\
\hline 26. $\mathrm{H}$ & telry service & Hostelry service cl & geosite & & \\
\hline 27. $R e$ & aurant service & Restaurant service & to geosite & & \\
\hline & Grades (0.00-1.00) & & & & \\
\hline & 0.00 & 0.25 & 0.50 & 0.75 & 1.00 \\
\hline 1. & Common & Regional & National & International & The only occurence \\
\hline 2. & None & Low & Moderate & High & Utmost \\
\hline 3. & None & Local publications & Regional publications & National publications & $\begin{array}{l}\text { International } \\
\text { publications }\end{array}$ \\
\hline
\end{tabular}




\begin{tabular}{|c|c|c|c|c|c|}
\hline & 0.00 & 0.25 & 0.50 & 0.75 & 1.00 \\
\hline 4. & None & $\begin{array}{l}\text { Moderate level of } \\
\text { processes but hard to } \\
\text { explain to non experts }\end{array}$ & $\begin{array}{l}\text { Good example of } \\
\text { processes but hard to } \\
\text { explain to non experts }\end{array}$ & $\begin{array}{l}\text { Moderate level of } \\
\text { processes but easy to } \\
\text { explain to common } \\
\text { visitor }\end{array}$ & $\begin{array}{l}\text { Good example of } \\
\text { processes and easy to } \\
\text { explain to common } \\
\text { visitor }\end{array}$ \\
\hline 5. & None & 1 & 2 to 3 & 4 to 6 & More than 6 \\
\hline 6. & Small & - & Medium & - & Large \\
\hline 7. & - & Low & Medium & High & Utmost \\
\hline 8. & Unfitting & - & Neutral & - & Fitting \\
\hline 9. & $\begin{array}{l}\text { Totally damaged (as } \\
\text { a result of human } \\
\text { activities) }\end{array}$ & $\begin{array}{l}\text { Highly damaged (as } \\
\text { a result of natural } \\
\text { processes) }\end{array}$ & $\begin{array}{l}\text { Medium damaged } \\
\text { (with essential } \\
\text { geomorphologic } \\
\text { features preserved) }\end{array}$ & Slightly damaged & No damage \\
\hline 10. & None & Local & Regional & National & International \\
\hline 11. & $\begin{array}{l}\text { Irreversible (with } \\
\text { possibility of total loss) }\end{array}$ & $\begin{array}{l}\text { High (could be easily } \\
\text { damaged) }\end{array}$ & $\begin{array}{l}\text { Medium (could be } \\
\text { damaged by natural } \\
\text { processes or human } \\
\text { activities) }\end{array}$ & $\begin{array}{l}\text { Low (could be damaged } \\
\text { only by human } \\
\text { activities) }\end{array}$ & None \\
\hline 12. & 0 & 0 to 10 & 10 to 20 & 20 to 50 & More than 50 \\
\hline 13. & Inaccessible & $\begin{array}{l}\text { Low (on foot with } \\
\text { special equipment and } \\
\text { expert guide tours) }\end{array}$ & $\begin{array}{l}\text { Medium (by bicycle and } \\
\text { other means of man- } \\
\text { powered transport) }\end{array}$ & High (by car) & Utmost (by bus) \\
\hline 14. & None & 1 & 2 to 3 & 4 to 6 & More than 6 \\
\hline 15. & None & 1 & 2 to 3 & 4 to 6 & More than 6 \\
\hline 16. & More than $100 \mathrm{~km}$ & 100 to $50 \mathrm{~km}$ & 50 to $25 \mathrm{~km}$ & 25 to $5 \mathrm{~km}$ & Less than $5 \mathrm{~km}$ \\
\hline 17. & None & Local & Regional & National & International \\
\hline 18. & None & Low & Medium & High & Utmost \\
\hline 19. & None & Local & Regional & National & International \\
\hline 20. & None & Less than 12 per year & 12 to 24 per year & 24 to 48 per year & More than 48 per year \\
\hline 21. & More than $50 \mathrm{~km}$ & 50 to $20 \mathrm{~km}$ & 20 to $5 \mathrm{~km}$ & 5 to $1 \mathrm{~km}$ & Less than $1 \mathrm{~km}$ \\
\hline 22. & None & Low quality & Medium quality & High quality & Utmost quality \\
\hline 23. & None & Low (less than 5000) & $\begin{array}{l}\text { Medium (5001 to } 10 \\
000 \text { ) }\end{array}$ & $\begin{array}{l}\text { High (10 } 001 \text { to } 100 \\
000)\end{array}$ & $\begin{array}{l}\text { Utmost (more than } 100 \\
\text { 000) }\end{array}$ \\
\hline 24. & None & Low & Medium & High & Utmost \\
\hline 25. & None & Low & Medium & High & Utmost \\
\hline 26. & More than $50 \mathrm{~km}$ & $25-50 \mathrm{~km}$ & $10-25 \mathrm{~km}$ & $5-10 \mathrm{~km}$ & Less than $5 \mathrm{~km}$ \\
\hline 27. & More than $25 \mathrm{~km}$ & $10-25 \mathrm{~km}$ & $10-5 \mathrm{~km}$ & $1-5 \mathrm{~km}$ & Less than $1 \mathrm{~km}$ \\
\hline
\end{tabular}

further divided into 12 and 15 indicators respectively, each individually marked from o to 1 . This division is made due to two general kinds of values: main - that are mostly generated by geosite's natural characteristics; and additional - that are mostly human-induced and generated by modifications for its use by visitors. The Main Values comprise three groups of indicators: scientific/educational (VSE), scenic/aesthetical values (VSA) and protection (VPr) while the Additional Values are divided into two groups of indicators, functional (VFn) and touristic values (VTr). The Main and Additional Values are more detailed presented in table 1. In total sum, there are 12 subindicators of Main Values, and 15 subindicators of Additional Values which are graded from o to 1 that define M-GAM as a simple equation:

$$
\mathrm{M}-\mathrm{GAM}=\mathrm{MV}+\mathrm{AV}
$$

where MV and AV represent symbols for Main and Additional Values. Since Main and Additional Values consist of three or two groups of subindicators, we can derive these two equations:

$$
\begin{aligned}
& \mathrm{MV}=\mathrm{VSE}+\mathrm{VSA}+\mathrm{VPr}, \\
& \mathrm{AV}=\mathrm{VFn}+\mathrm{VTr},
\end{aligned}
$$

Now that we know that each group of indicators consists of several subindicators, equations (2) and (3) can be written as follows: 


$$
M V=V S E+V S A+V \operatorname{Pr}=\sum_{i=1}^{12} S I M V_{i}
$$

where, $0 \leq S I M V_{i} \leq 1$

$$
A V=V F n+V \operatorname{Tr}=\sum_{j=1}^{15} S I A V_{i}
$$

where, $0 \leq S I A V_{j} \leq 1$.

Here, $S I M V_{i}$ and $S I A V_{j}$ represent 12 subindicators of Main Values $(i=1, \ldots, 12)$ and 15 subindicators $(j=$ $1, \ldots, 15)$ of Additional Values.

While in GAM all grades for each subindicator are given by experts M-GAM, focuses not only on the expert's opinion but also on the opinion of visitors and tourists regarding the importance of each indicator in the assessment process. Visitor inclusion in the assessment process is done through a survey where each respondent is asked to rate the importance (Im) of all 27 subindicators (from 0.00 to 1.00 ) in the M-GAM model (Table 2). The importance factor (Im) gives visitors the opportunity to express their opinion about each subindicator in the model and how important it is for them when choosing and deciding between several geosites that they wish to visit. After each respondent rates the importance of every subindicator, the average value of each subindicator is calculated and the final value of that subindicator is the importance factor. Afterwards, the value of the importance factor $(I m)$ is multiplied with the value that was given by experts (also from 0.00 to 1.00) who evaluate the current state and value of subindicators (Table 2).

This is done for each subindicator in the model after which the values are added up according to M-GAM equation but this time with more objective and accurate final results due to the addition of the importance factor (Im). This parameter is determined by visitors who rate it in the same way as experts rate the subindicators for Main and Additional Values by giving them one of the following numerical values: $0.00,0.25,0.50$, 0.75 and 1.00, marked as points. The importance factor (Im) is defined, as:

$$
I m=\frac{\sum_{k=1}^{K} I v_{k}}{K}
$$

Where $I v_{k}$ is the assessment/score of one visitor for each subindicator and $K$ is the total number of visitors. Note that the Im parameter can have any value in the range from 0.00 to 1.00 .

Finally, the modified GAM equation is defined and presented in the following form:

$$
\begin{aligned}
& \mathrm{M}-\mathrm{GAM}=\mathrm{MV}+\mathrm{AV} \\
& M V=\sum_{i=1}^{n} \operatorname{Im}_{i} \cdot M V i \\
& A V=\sum_{i=1}^{n} \operatorname{Im}_{j} \cdot A V_{j}
\end{aligned}
$$

As it can be seen from the M-GAM equation, the value of the importance factor (Im), which is rated by visitors (for each subindicator separately) is multiplied with the value given by experts (also separately for each subindicator). This is done for each subindicator in the model. Therefore, the values of $M-G A M$ sub-indicators are always equal or less than GAM values.

In their research about different geotouristic segments, Božić \& Tomić (2015) conducted a survey and calculated the importance factor for each subindicator in the M-GAM model. Therefore, the values of the importance factor in this paper have been adopted from the mentioned paper.

Based on the assessment results, a matrix of Main ( $\mathrm{X}$ axes) and Additional Values ( $\mathrm{Y}$ axes) is created (Figure 7). The matrix is divided into nine fields represented with $Z(i, j)$, $(i, j=1,2,3)$. Depending on the final score, each geosite will fit into a certain field. For example, if a geosite's Main Values are 7 and additional are 4 , the geosite will fit into the $Z_{21}$ field. 


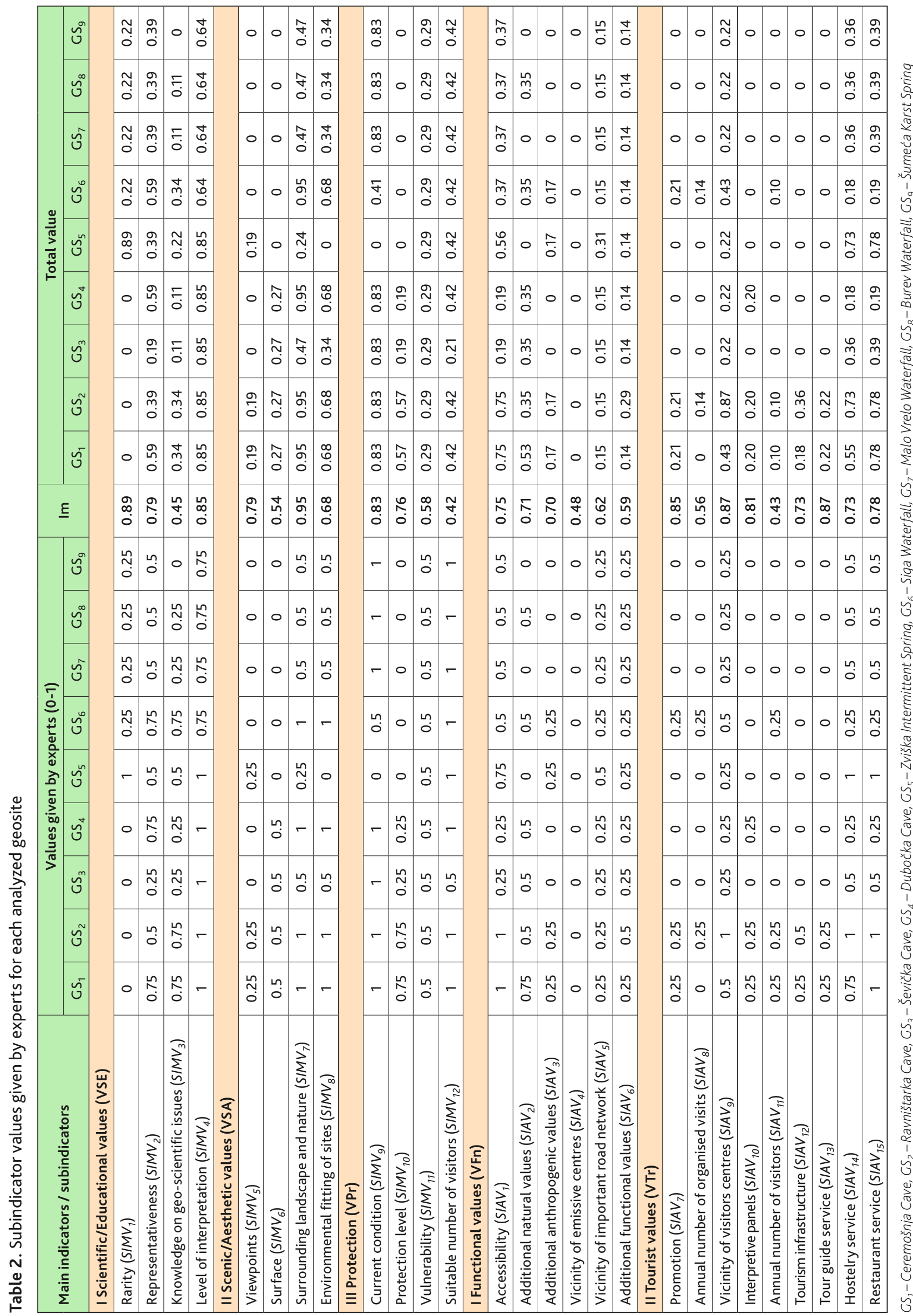




\section{Results and discussion}

Based on the assessment results we can see a notable difference in the assessment values between speleological and hydrological karst geosites. Speleological geosites are quite common in this region, therefore they received the lowest grade for rarity (o). As far as hydrological karst geosites are concerned, the results are slightly different. Waterfalls Siga, Burev and Little Spring represent a regional phenomenon, and they were given a score of 0.25. The karst hot spring Šumeća was also given a score of 0.25 eventhough karst springs usually represent a frequent occurrence in karst areas. However, in the Pek River Basin they represent regional geosites. The Zviška Intermittent Spring was given the highest score because it represents a very rare natural phenomenon on an international level. The subindicator related to knowledge on geoscientific issues is rated differently for each geosite. Ceremošnja and Ravništarka caves have generally higher scores than the other two caves. This is partly because these two caves were explored and protected on a national level and scientific papers about these caves were published in national publications. Dubočka and Ševička caves have a score of 0.25 , which means they have only been explored at a local level. The karst geosite Zviška was rated with a medium value of 0.5 which is very unfortunate because this geosite represents a very rare natural occurance and more attention should have been focused towards it in the past. The Siga Waterfall was the highest rated waterfall mainly due to the fact that it is the most well known in the Kučevo municipality. The interpretation level for the analyzed geosites was rated the highest of all subindicators within the group of scientific values. All speleological objects have the maximum score due to the fact that they represent good examples of geological and geomorphological phenomena related to their origin and current state can be easily explained to the common visi- tor. Springs and waterfalls are also highly rated, just slightly less than caves which means that they possess a moderate level of geomorphological processess that are easy to explain to common visitors.

When it comes to Scenic/Aesthetic values, we can notice that the highest rated subindicator in this group is related to environmental fitting of geosites. All speleological sites, apart from Ševička Cave have the maximum score for this subindicator. Little Spring and Burev waterfalls are evaluated with a score of 0.5, the same as the karst spring of Sumeća. The Siga waterfall with its almost hidden forest location was rated the highest. The lowest rated subindicator in this group is related to viewpoints because there are only a few. One of the best is located in the vicinity of the Ceremošnja Cave, at the $940 \mathrm{~m}$ high top of Veliki Štubej. The other is located near the center of Kučevo.

In case of protection values, the subindicators for current state and carrying capacity received the highest score, while level of protection is rated lowest. The vulnerability level of the analyzed geosites was rated medium, which means that they can be damaged by natural processes or human activities. Most of the geosites are currently not damaged apart from Zviška Spring and Siga Waterfall. The waterfall got a score of 0.5 for its current condition due to an increasing lack of water for longer periods than in previous years which significantly affects its tourist potential. Zviška Spring received the lowest grade due to damage through human activities originating from the abandoned industrial zone that was once here.

In terms of Additional values we can notice that Ravništarka and Ceremošnja caves have the highest additonal values while Dubočka Cave has the lowest, followed closely by Malo Vrelo Waterfall and Šumeća Karst Spring (Table 3).

Table 3. Overall ranking of the analyzed geosites by M-GAM

\begin{tabular}{|c|c|c|c|c|c|}
\hline \multirow{2}{*}{ Geosite Label } & \multicolumn{2}{|c|}{ Main values } & \multicolumn{2}{|c|}{ Additional values } & \multirow{2}{*}{ Field } \\
\hline & VSE + VSA + VPr & $\Sigma$ & $V F n+V T r$ & $\Sigma$ & \\
\hline Ceremošnja Cave - $\mathrm{GS}_{1}$ & $1.78+2.29+2.11$ & 6.18 & $1.74+2.67$ & 4.41 & Z21 \\
\hline Ravništarka Cave - $\mathrm{CS}_{2}$ & $1.58+2.09+2.11$ & 5.78 & $1.71+3.61$ & 5.32 & Z22 \\
\hline Ševička Cave - $\mathrm{GS}_{3}$ & $1.15+1.08+1.52$ & 3.75 & $0.83+0.97$ & 1.8 & Z11 \\
\hline Dubočka Cave - $\mathrm{CS}_{4}$ & $1.55+1.90+1.73$ & 5.18 & $0.83+0.79$ & 1.62 & Z21 \\
\hline Zviška Intermittent Spring - $\mathrm{GS}_{5}$ & $2.35+0.43+0.71$ & 3.49 & $1.18+1.73$ & 2.91 & Z11 \\
\hline Siga Waterfall - $\mathrm{GS}_{6}$ & $1.79+1.63+1.12$ & 4.54 & $1.18+1.25$ & 2.43 & $\mathrm{Z} 21$ \\
\hline Little Spring Waterfall - $\mathrm{GS}_{7}$ & $1.36+0.81+1.54$ & 3.71 & $0.66+0.97$ & 1.63 & Z11 \\
\hline Burev Waterfall - $\mathrm{GS}_{8}$ & $1.36+0.81+1.54$ & 3.71 & $1.01+0.97$ & 1.98 & $\mathrm{Z11}$ \\
\hline Šumeća Karst Spring - GS & $1.25+0.81+1.54$ & 3.6 & $0.66+0.97$ & 1.63 & Z11 \\
\hline
\end{tabular}


Within Functional values, accessibility is rated highest, while the vicinity of emissive centers is rated lowest. The accessibility of Ceremošnja and Ravništarka caves is highest as they are both accessible by asphalt roads and reachable by bus. All of the waterfalls have a lower level of accesibility as they are only approachable by bike or on foot. Dubočka and Ševička caves have the lowest level of accessibility as they require the help of an experienced guide and are located a few kilometers away from the nearest road. Additional functional values are very low for each geosite because there are no parking lots (besides the ones near Ceremošnja and Ravništarka caves), gas stations and other similar facilitites nearby.

The final group of subindicators is related to tourist value. Hostelry and restaurant service were rated highest while promotion, organized visits, interpretive panels, number of visitors, tourist infrastructure and tour guide service were rated poorly.

Current promotional activities are done by the Tourist Organization of Kučevo mainly at the local level. However, it is only for Ceremošnja and Ravništarka caves as well as for the Siga Waterfall. Other geosites are currently neglected. Another problem is that there are very few, if any, organized visits to the majority of the analyzed geosites. The tourist organization and geosite management do not precisely keep track of visitor numbers. According to their estimations there are less than 5000 visitors per year at Ravništarka and Ceremošnja caves, while other geosites are much less visited. Tourist infrastructure and guide service only exist at the Ravništarka and Ceremošnja geosites, with Ravništarka offering a better quality service and overall experience.

By comparing the final results for all analyzed geosites we can clearly detect their position in the MGAM matrix (Figure 7) based on their Main and Additional Values. From the displayed matrix we can see that five geosites (Ševička Cave, Zviška Spring, Šmeća Karst Spring, Little Spring and Burev Waterfalls) are located within the $Z_{11}$ field, three geosites (Siga Waterfall, Ceremošnja and Dubočka caves) are located in the $Z_{21}$ field while the only geosite in the $Z_{22}$ field is Ravništarka Cave.

Looking at the final results in the matrix we can clearly notice that speleological geosites are better positioned compared to other geosites. From the hydrological karst geosites, only Siga Waterfall is in the $Z_{21}$ field, while the others are in $Z_{11}$. Other waterfalls are located in the $Z_{11}$ field, near the border with the $Z_{21}$ field meaning they have similar values to Siga waterfall but slightly lower than Siga. As for the caves, Ceremošnja and Ravništarka are located near the border between fields $Z_{21}$ and $Z_{22}$. Ravništarka Cave is in a better position due to its higher Additional values. However, Ceremošnja Cave has slightly higher

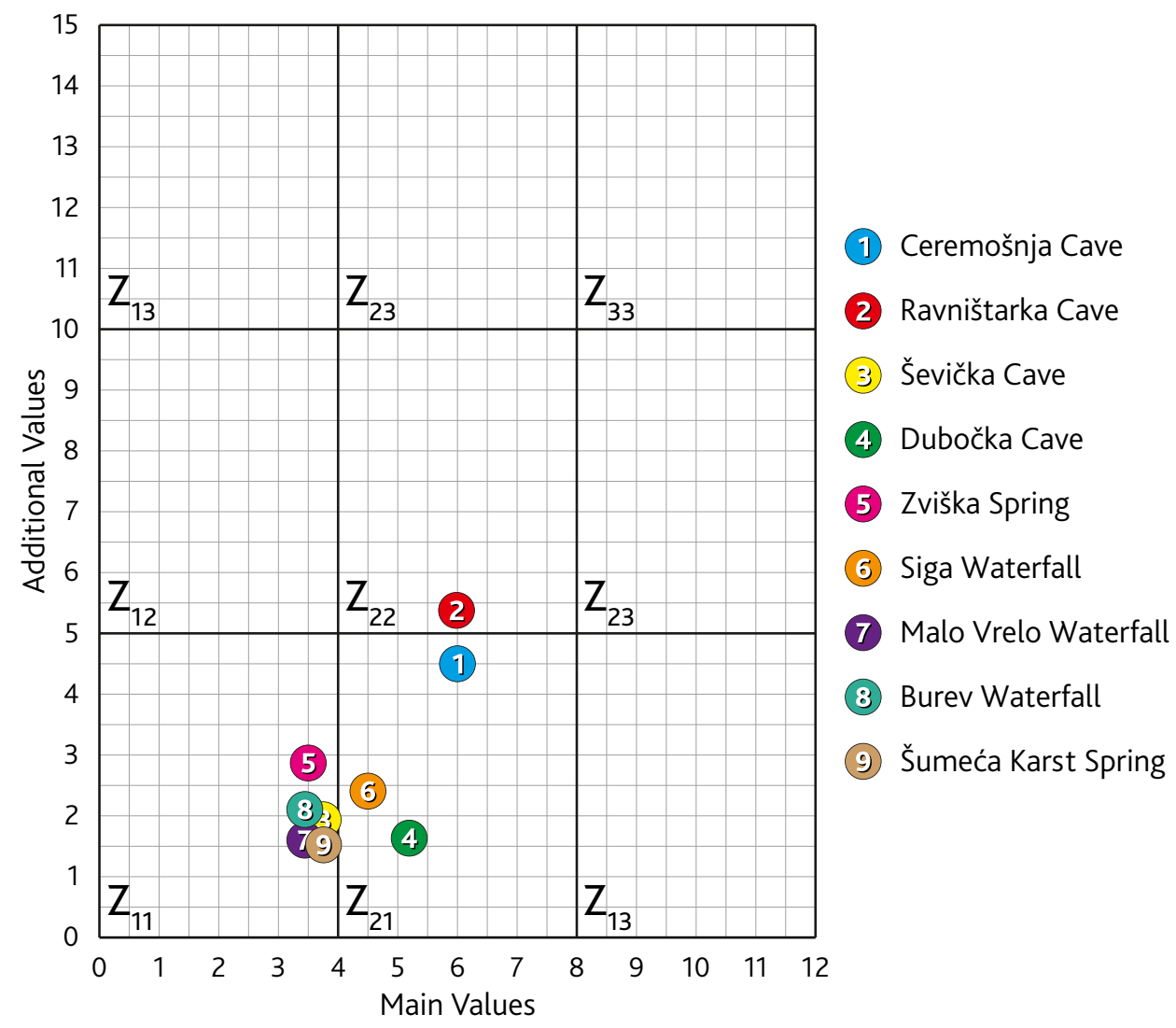

Figure 7. Position of analyzed geosites in the M-GAM matrix 
Main Values. Dubočka Cave also has good Main Values, however it cannot compete with Ravništarka and Ceremošnja when it comes to Additional Values.

Based on our results we can see that future activities should be focused towards improving such elements as tour guide service, interpretive panels, tourist infrastructure and visitor center contents. Also, the majority of analyzed geosites (apart from Ceremošnja and Ravništarka cave) still remain without protection from the Nature Conservation Institute of Serbia, eventhough some of them deserve at least the lowest level of protection status. Future tourism development of this region should be primarily focused towards cave tourism. Ravništarka and Ceremošnja caves already possess some of the tourist infrastructure and other elements neccessary for tourism development which should be fully utilized in their current condition and improved in the coming years. Dubočka and Ševička caves lack the necessary infrastructure and they are not for average cave tourists. These two caves can be used for adventure speleotourism through smaller investments in spelunking equipment and expert tour guide service which could transform these two geosites into a speleo adventure destination. Other analyzed geosites included waterfalls and springs. None of these sites possess any kind of infrastructure, often not even a proper road sign indicating their location. Rectifying this would be a significant initial step towards the inclusion of these sites into the tourism offer of Kučevo.

In their paper about speleotourism in Eastern Serbia, Tomić et al. (2018) analyzed six speleological geosites by applying M-GAM. According to their results, the highest rated cave was Resavska Cave, one of the most popular caves in Serbia, with Ravništarka Cave getting a lower final score. If we compare our results with this we can notice that Ravništarka Cave now has slightly higher Main and Additional Values than Resavska Cave. The main reason behind this improvement is related to several infrastructural improvements that have been done recently. Thanks to these recent activities Ravništarka and Ceremošnja Cave can now easily match Resavska and Rajkova Cave on the national tourism market. In order to do this successfully and attract a larger number of tourists in the future, it is necessary to improve the tour guide service and promotional activities of these caves as well as to establish a long lasting and stable management organization that would take care of tourism activities at these sites. For the moment, this job is entrusted to the tourism organization of Kučevo whose activities and human effort play a key role in the future tourism development of this area.

Furthermore, if we compare our results to those of Tičar et al. (2018) who analyzed caves and speleotourism in Slovenia, we can notice that tourist caves in Slovenia do not possess much higher Main Values than the ones analyzed in this paper. However, when it comes to Additional Values there is a clear difference. Slovenian caves are much higher rated than Serbian ones. The main reason behind this is connected with human interventions and the level of tourism infrastructure which is much higher than in Serbian caves. One of the reasons is also a longer cave tourism tradition in Slovenia and the vicinity of bigger tourist destinations and especially the direct connection to main tourist flows from Western and Central Europe towards the Mediterranean (Adriatic Sea). The implementation of a similar cave management model in Serbia would for sure benefit further speleotourism development.

If we compare our assessment results to those of other karst geosites in Serbia such as canyons and gorges, we can notice that caves have higher values than some of them. According to research done by Božić et al. (2014), Ravništarka and Ceremošnja Cave have a better position in the M-GAM matrix than Lazar and Uvac Canyon. Once again, the main reason behind this is related to the level of Additional Values and the human factor, the same as in the case of Slovenian caves. However, if we look at the results from Božić and Tomić (2015) and their analysis of canyons and gorges in Serbia, we can see that the Đerdap Gorge has much higher results and a better position in the M-GAM matrix than any of the geosites analyzed in this paper. By analyzing and comparing research done on this topic in Serbia, it would seem that at the moment caves and speleotourism have a slight advantage over canyons and gorges when it comes to tourism development. More attention is focused towards caves in general as well as towards their infrastructure and tourism development. However, further research on this topic is necessary in order to definitely confirm or disprove this fact in the future.

\section{Conclusion}

The speleological and hydrological karst geoheritage in the Pek River lower basin includes a diverse and wide range of natural values. Speleological objects have the highest tourist value and potential which is why they should be the base for tourism development in this area. On the other hand, karst waterfalls and springs lack the basic tourist infrastructure which is the main problem of these geosites. Improvement of transport, communal and tourist infrastructure is not only neccessary for further tourism development but also as a 
basis for further development of the local and regional economy. The analyzed geosites possess all of the necessary elements for geotourism development apart from the human factor and effort focused towards improving the Additional Values of these geosites in the future. One of the necessary activities is also to continually monitor speleotourism trends throughout the world so that the analyzed caves can be competitive on this market. The value of these caves certainly provides a possibility for their recognition on the global speleotourism market. However, this has not been the case so far. Based on our results we can notice that there is still plenty of work to be done especially in the area of infrastructure and other elements related to Additional Values. One of the future goals should be better promotional activities on a national and international level as well as better road signalization and tour guide service. Significant improvement of these elements would bring a much larger number of tourists to these sites which would also benefit the local economy through higher revenue and additional jobs for the local community.

\section{References}

Antić, A., \& Tomić, N. (2017). Geoheritage and geotourism potential of the Homolje area (e a s t e r $n$ Serbia). Acta Geoturistica, 8(2), 67-78.

Boškov, J., Kotrla, S., Jovanović, M., Tomić, N., Lukić, T., \& Rvović, I. (2015). Application of the preliminary geosite assessment model (GAM): the case of the Bela Crkva municipality (Vojvodina, North Serbia). Geographica Pannonica, 19(3), 146-152.

Božić, S., Tomić, N., \& Pavić, D. (2014). Canyons as potential geotourism attractions of Serbia - comparative analysis of Lazar and Uvac canyons by using M-GAM model. Acta Geoturistica, 5(2), 18-30.

Božić, S., \& Tomić, N. (2015). Canyons and gorges as potential geotourism destinations in $\mathrm{S}$ e $\mathrm{r}$ b i a : Comparative analysis from two perspectives - General tourists' and pure geotourists'. Open Geosciences, 7, 531-546.

Brilha, J. (2016). Inventory and quantitative assessment of geosites and geodiversity sites: a review. Geoheritage, 8(2), 119-134.

Bruschi, V. M., \& Cendrero, A. (2005). Geosite evaluation. Can we measure intangible values? Il Quaternario,18(1), 293-306.

Coratza, P., \& Giusti, C. (2005). Methodological proposal for the assessment of the scientific quality of geomorphosites. Il Quaternario, 18(1), 307-313.

Dowling, R., \& Newsome, D. (2010). Geotourism: A global activity. In R. Dowling, \& D. Newsome (Eds.), Global geotourism perspectives (pp. 1-17). Woodeaton: Goodfellow Publishers.

Erhartič, B. (2010). Geomorphosite assessment. Acta Geographica Slovenica, 50(2), 295-319.

Farsani, N. T., Coelho, C. O. A., \& Costa, C. M. M. (2014). Analysis of network activities in geoparks as geotourism destinations. International Journal of Tourism Research,16, 1-10.

Fassoulas, C., Mouriki, D., Dimitriou-Nikolakis, P., \& Iliopoulos, G. (2012). Quantitative as-sessment of geotopes as an effective tool for geoheritage management. Geoheritage, 4, 177-193.
Gray, M. (2004). Geodiversity: Valuing and Conserving Abiotic Nature. Chichester: John Wiley \& Sons.

Hose, T. A. (1997). Geotourism - selling the earth to Europe. In P. G., Marinos, G. Koukis, C. Tsiambaos, \& G. C. Stournaras (Eds.), Engineering geology and the environment (pp. 2955-2960). Rotterdam: A.A Balkema.

Hose, T. A. (2000). European'geotourism' - Geological interpretation and conservation promotion for tourists. In D. Barettino, W. A. P. Wimbledon, \& E. Gallego (Eds.), Geo-logical heritage: Its conservation and management (pp. 127-146). Madrid: ITGE.

Hose, T. A., \& Vasiljević, Dj. A. (2012). Defining the nature and purpose of modern geotourism with particular reference to the United Kingdom and south-east Europe. Geoheritage, 4, 25-43

Krešić, N. (1988). Karst i pećine Jugoslavije [Karst and caves of Yugoslavia]. Belgrade: Naučna knjiga (in Serbian).

Kubalíková, L., \& Kirchner, K. (2016). Geosite and geomorphosite assessment as a tool for geoconservation and geotourism purposes: a case study from Vizovická vrchovina Highland (eastern part of the Czech Republic). Geoheritage, 8(1), 5-14.

Lazarević, R. (1988). Pećina Ceremošnja [Ceremošnja Cave]. Kučevo: Partizan (in Serbian).

Lazarević, R. (1991). Kraški izvor Kučevo [Kučevo Karst Spring]. Kučevo: Partizan (in Serbian).

Lazarević, R. (1993). Pećina Ravništarka [Ravništarka Cave]. Kučevo: Partizan (in Serbian).

Lazarević, R. (2001). Dubočka Pećina [Dubočka Cave]. Belgrade: Serbian Geographical Society (in Serbian).

Pereira, P., Pereira, D., \& Caetano Alves, M. I. (2007). Geomorphosite assessment in Montesinho Natural Park (Portugal). Geographica Helvetica, 62, 150-168.

Pralong, J.-P. (2005). A method for assessing the tourist potential and use of geomorphological sites. Géomorphologie. Relief, processes, environnement, 3, 189-196. 
Pralong, J.P. (2006). Geotourism: A new Form of Tourism utilising natural Landscapes and based on Imagination and Emotion. Tourism Review, 61(3), 20-25.

Rajković, I. (2014). Turistički potencijal opštine Kučevo [Tourist potential of Kučevo Municipality]. Novi Sad: Faculty of Science (in Serbian).

Reynard, E. (2008). Scientific research and tourist promotion of geomorphological heritage. Geografia fisica e dinamica quaternaria, 31(2), 225-230.

Reynard, E., Fontana, G., Kozlik, L., \& Scapozza, C. (2007). A method for assessing "scientific“ „additional values" of geomorphosites. Geographica Helvetica, 62(3), 148-158.

Różycka, M., \& Migoń, P. (2014). Visitors' background as a factor in geosite evaluation. The case of Cenozoic volcanic sites in the Pogórze Kaczawskie region, SW Poland. Geotourism/Geoturystyka, 34(38), 3-18.

Różycka, M., Migoń, P. (2018). Customer-Oriented Evaluation of Geoheritage-on the Example of Volcanic Geosites in the West Sudetes, SW Poland. Geoheritage, 10(1), 23-37.

Ruban, D. A. (2015). Geotourism - A geographical review of the literature. Tourism Management Perspectives, 15, 1-15.

Rybár, P. (2010). Assessment of attractiveness (value) of geotouristic objects. Acta Geoturistica, 1(2), 13-21.

Serrano, E., \& González-Trueba, J. J. (2005). Assessment of geomorphosites in natural protected areas: the Picos de Europa National Park (Spain). Géomorphologie. Formes, processus, environnement, 3, 197-208.

Suzuki, D. A., Takagi, H. (2018). Evaluation of Geosite for Sustainable Planning and Management in Geotourism. Geoheritage, 10(1), 123-135.

Štrba, L. (2015). Identification and evaluation of geosites along existing tourist trail as a primary step of geotourism development: case study from the Spiš region (Slovakia). GeoJournal of Tourism and Geosites, 16, 126-140.

Štrba, L. (2018). Analysis of Criteria Affecting Geosite Visits by General Public: a Case of Slovak (Geo) Tourists. Geoheritage, 1-10, https://doi.org/10.1007/ s12371-018-0283-2

Štrba, L., Rybár, P., Baláž, B., Molokáč, M., Hvizdák, L., Kršák, B., Lukáč, M., Muchová, L., Tometzová,
D., \& Ferenčíková, J. (2015). Geosite assessments: comparison of methods and results. Current Issues in Tourism, 18(5), 496-510.

Tičar, J., Tomić, N., Breg Valjavec, M., Zorn, M., Marković, S.B., \& Gavrilov, M.B. (2018).

Speleotourism in Slovenia: balancing between mass tourism and geoheritage protection. Open Geosciences, 10, 344-357.

Tomić, N. (2011). The potential of Lazar Canyon (Serbia) as a geotourism destination: inventory and evaluation. Geographica Pannonica, 15(3), 103-112.

Tomić, N., Marković, S.B., Korać, M., Mrđić, N., Hose, T.A., Vasiljević, Dj.A., Jovičić, M., \& Gavrilov, M.B. (2015). Exposing mammoths: from loess research discovery to public palaeontological park. Quaternary International, 372, 142-150.

Tomić, N., \& Božić, S. (2014). A modified geosite assessment model (M-GAM) and its ap plic ation on the Lazar Canyon area (Serbia). International Journal of Environmental Research, 8(4), 1041-1052.

Tomić, N., Antić, A., Marković, S.B., Đorđević, T., Zorn, M., \& Breg Valjavec, M. (2018). Exploring the potential for speleotourism development in eastern Serbia. Geoheritage, 1-11. https://doi. org/10.1007/s12371-018-0288-x

Vujadinović, S. (1953). Privredno geografske $i$ saobraćajne odlike sliva Peka [Economic, geographic and transport system characteristics of the Pek River basin]. Belgrade: Jovan Cvijić Geographical Institute (in Serbian).

Vujičić, M. D., Vasiljević, Dj. A., Marković, S. B., Hose, T. A., Lukić, T., Hadžić, O., \& Janićević, S. (2011). Preliminary geosite assessment model (GAM) and its application on Fruška Gora Mountain, potential geotourism destination of Serbia. Acta Geographica Slovenica, 51, 361-377

Vukoičić, D., Milosavljević, S., Valjarević, A., Nikolić, M., \& Srećković-Batoćanin, D. (2018). The evaluation of geosites in the territory of National park „Kopaonik“ (Serbia). Open Geosciences, 10, 618-633. https://doi.org/10.1515/geo-2018-0049

Zouros, N. C. (2007). Geomorphosite assessment and management in protected areas of Greece. The case of the Lesvos island coastal geomorphosites. Geographica Helvetica, 62, 169-180. 